\title{
A CHAIN OF KINGS
}


The Bibliotheca Indonesica is a series published by the Koninklijk Instituut voor Taal-, Land- en Volkenkunde (Royal Netherlands Institute of Southeast Asian and Caribbean Studies), Leiden. The series contains critical editions of texts in various Indonesian languages, together with a translation and commentary in English. 


\title{
BIBLIOTHECA INDONESICA
}

\author{
published by the \\ KONINKLIJK INSTITUUT \\ VOOR TAAL-, LAND- EN VOLKENKUNDE
}

33

\section{A CHAIN OF KINGS}

The Makassarese chronicles of Gowa and Talloq

edited and translated by

\author{
WILLIAM CUMMINGS
}

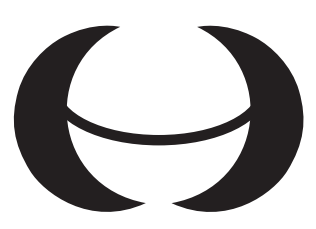

KITLV Press

Leiden

2007 
Published by:

KITLV Press

Koninklijk Instituut voor Taal-, Land- en Volkenkunde

(Royal Netherlands Institute of Southeast Asian and Caribbean Studies)

P.O. Box 9515

2300 RA Leiden

The Netherlands

website: www.kitlv.nl

e-mail: kitlvpress@kitlv.nl

KITLV is an institute of the Royal Netherlands Academy of Arts and Sciences (KNAW)

Cover: Creja ontwerpen, Leiderdorp

ISBN 9789067182877

(C) 2007 Koninklijk Instituut voor Taal-, Land- en Volkenkunde

No part of this publication may be reproduced or transmitted in any form or by any means, electronic or mechanical, including photocopy, recording, or any information storage and retrieval system, without permission from the copyright owner.

Printed in the Netherlands 


\section{Contents}

Preface

Abbreviations

I Introduction

The chronicles' history of pre-colonial Makassar 1

Historiographical comments 8

II The chronicle texts

Description of manuscripts 13

Chronicle composition 18

Translating Makassarese texts 25

III The Gowa chronicle

Translation 29

Appendix 149

Notes 50

Transliteration 65

IV The Talloq chronicle

Translation 83

Notes 93

Transliteration 97

Glossary

Reign list for the rulers of Gowa and Talloq

Bibliography

Index 
William Cummings - 9789004254008

Downloaded from Brill.com๑4/26/2023 09:41:16AM

via free access 


\section{Preface}

The opening invocation of the Gowa chronicle states that it commemorates the karaeng, or rulers, of Gowa by recounting their names so that they will not be forgotten. 'Because if they are not known there are two dangers: either we will feel ourselves to be such karaeng or outsiders will say you here are just common people.' This book has been written for those very outsiders that a chronicler some four centuries ago believed would otherwise overlook the history of this corner of the world. Translations of the two main chronicles written at the courts of Gowa and Talloq offer readers a window on a tumultuous chapter in Indonesia's long history. These two close allies dominated Makassar and a substantial portion of South Sulawesi before their conquest by the Verenigde Oost-Indische Compagnie (VOC, Dutch East Indies Company) and Bugis in 1669, and it is largely through these chronicles that we know what transpired in Makassar before this date.

The chronicles of Gowa and Talloq are the most important historical sources for the study of pre-colonial Makassar. They have provided the basic framework and much of the information that we possess about the origins, growth, and expansion of Gowa during the sixteenth and seventeenth centuries. During this period Gowa and its close ally Talloq became the most powerful force in the eastern Indonesian archipelago, and historians have relied heavily on Indonesian translations of the chronicles (Wolhoff and Abdurrahim 1959; Rahim and Ridwan 1975) to chart the developments of this period. Unfortunately, the Indonesian translations contain numerous errors, have a tendency to gloss over difficult passages, and were based on a published transcription (Matthes 1883), itself based on manuscripts that in hindsight were not the best choice. J. Noorduyn described them as 'less convincing on every point' (Noorduyn 1991:481). Since so few scholars can read Makassarese, a careful translation of the chronicles will offer historians an invaluable foundation on which to base interpretations of this crucial place and time in Indonesian history.

In addition to their role as sources of historical information, the two chronicles are extremely valuable historiographically. Careful translations provide scholars the opportunity to examine how the chronicles were narratively constructed, how their structure and form related to their content, and 
how chronicle writing was connected to social formations and social changes during the pre-modern period. Such translations can also facilitate investigations of Makassarese notions of history, identity, power, religion, society, and a host of other ethnographic topics. Careful and critical examinations of the chronicles as a whole or of individual reigns or themes can yield valuable information about Makassarese perceptions of their social world.

This book is divided into two main sections. The first pair of chapters examines what we can know of pre-colonial Makassarese history (and what we cannot) through the chronicles. This includes the historical background of pre-colonial Makassar as well as careful consideration of the textual issues surrounding the extant manuscripts containing the chronicles and that affect their transcription, translation, and interpretation. A glossary and reign lists for the rulers of Gowa and Talloq will help readers navigate the translated texts. The second part of the book presents translations, explanatory notes, and transcriptions of the Gowa and Talloq chronicles.

Like all projects, this one has accumulated several years of professional and personal debts. Within the small field of South Sulawesi studies, Anthony Jukes, Campbell Macknight, and a diligent anonymous reader have provided support, advice, and saved me from numerous (though doubtless not all) errors. The University of South Florida and the department of History have provided a collegial atmosphere in which to pursue this work. In particular I thank Mike Decker for the frequent coffee breaks. Andi Malarangeng and Jim Henry at Northern Illinois University developed the Bugis font used in the text. Above all others, however, I am deeply indebted to Sharon, without whose encouragement, love, and understanding this work would have little meaning. Terima kasih. 


\section{Abbreviations}

AL Lembaga Sejarah dan Antropologi, Cabang II ms. 2

ANRI Arsip Nasional Republik Indonesia

AS Lembaga Sejarah dan Antropologi, Cabang II ms. 1

BL British Library, Department of Oriental Manuscripts

CM Matthes, B.F., 1883, Makassaarsche chrestomathie; Oorspronkelijke Makassaarsche geschriften in proza en poëzij uitgegeven. 's-Gravenhage: Nijhoff.

KIT Koninklijk Instituut voor de Tropen

MS Matthes Stichting

NBG Nederlandsch Bijbelgenootschap

SPBK Staatsbibliothek Preussischer Kulturbesitz, Oriental Manuscripts

VOC Verenigde Oost-Indische Compagnie

VT Miscellaneous languages collection, Museum Nasional, Jakarta 